\title{
PENGARUH KEMANDIRIAN BELAJAR TERHADAP HASIL BELAJAR IPA
}

\section{THE INFLUENCE OF INDEPENDENCE LEARNING TO NATURAL SCIENCES LEARNING OUTCOMES}

\author{
RR Aliyyah ${ }^{1 a}$, FA Puteri' ${ }^{1}$ dan A Kurniawati ${ }^{1}$ \\ ${ }^{1}$ Program Studi Pendidikan Guru Sekolah Dasar, Fakultas Keguruan dan Ilmu Pendidikan, \\ Universitas Djuanda Bogor, Jl. Tol Ciawi No. 1 Kotak Pos 35 Ciawi Bogor 16720 \\ a Korespondensi: Rusi Rusmiati Aliyyah, Email: rusi.rusmiati@unida.ac.id \\ (Diterima: 14-08-2017; Ditelaah: 15-08-2017; Disetujui: 17-10-2017)
}

\begin{abstract}
This study aims to determine how the influence of independence learning on learning outcomes on science of fourth grade student of Pajajaran Bogor Elementary School. The method used is quantitative correlation approach functional. Research shows that there are significants between independence learning towards science learning outcomes. This is evidence by the results of the caculation of the $\mathrm{T}_{\text {test }}$ is independence learning with science learning outcomes obtained value $t_{\text {count }} 8,306$ which is more greater than table 2000 . And the significant value independence learning with learning results of 0,000 which is less than 0,05 then $\mathrm{Ho}$ is rejected and $\mathrm{Ha}$ is accepted. Coefficient of determination between the calculation result independence learning with Learning Outcomes of 53,50\% while 46,50\% are influenced by other factors.
\end{abstract}

Keywords: Independence Learning, Learning Outcomes.

\begin{abstract}
ABSTRAK
Penelitian ini ialah memiliki sebuah tujuan yaitu untuk mengetahui apakah ada pengaruhnya dari kemandirian belajar terhadap hasil belajar IPA siswa kelas IV SDN Pajajaran Bogor. Di dalam penelitian ini metode penelitiannya ialah kuantitatif dengan pendekatan korelasi fungsional. Setelah diadakannya penelitian, hasil menunjukkan bahwa terbukti adanya pengaruh antara kemandirian belajar terhadap hasil belajar IPA. Hal ini dibuktikan dengan hasil perhitungan uji t yaitu kemandirian belajar dengan hasil belajar IPA diperoleh nilai thitung sebesar 8,306 yang lebih besar dari nilai ttabel 2,000. Serta nilai signifikansi kemandirian belajar dengan hasil belajar sebesar 0,000 yang lebih kecil dari 0,05 maka Ho ditolak dan Ha diterima. Hasil perhitungan koefisien determinasi antara kemandirian belajar dengan hasil belajar sebesar 53,50\% sedangkan 46,50\% dipengaruhi oleh faktor-faktor lain.

Kata kunci: Kemandirian Belajar, Hasil Belajar.
\end{abstract}

Aliyyah RR, FA Puteri, dan A Kurniawati. 2017. Pengaruh kemandirian belajar terhadap hasil belajar IPA. Jurnal Sosial Humaniora 8(2): 126 - 143.

\section{PENDAHULUAN}

Banyak hal yang mempengaruhi kuantitas dan kualitas belajar siswa yang pada akhirnya akan mempengaruhi hasil belajarnya. Tingkat keberhasilan siswa dalam proses belajar dinyatakan dengan hasil belajarnya. Hasil pengetahuan belajar yang telah diraih oleh siswa memberikan gambaran tentang posisi tingkat dirinya dibandingkan siswa lain. Untuk mengetahui seseorang telah mengalami proses belajar dan telah mengalami perubahan-perubahan, 
baik perubahan dalam pengetahuan, keterampilan ataupun sikap maka dapat dilihat dari hasil belajarnya.

Dalam proses pembelajaran, setiap siswa memiliki karakteristik yang beragam. Ada siswa yang dapat mengikuti kegiatan belajar mengajar dengan baik dan ada juga siswa yang kesulitan di dalam mengikuti kegiatan belajar, terutama pada mata pelajaran IPA.

Pembelajaran IPA di Sekolah Dasar (SD) memiliki manfaat diantaranya memiliki keterampilan proses, siswa dapat menemukan fakta-fakta, membangun konsep-konsep, teori-teori, dan sikap ilmiah siswa itu sendiri yang akhirnya dapat berpengaruh positif terhadap kualitas proses pendidikan maupun produk pendidikan. Namun yang terjadi saat ini adalah masih banyak siswa yang kurang menguasai pelajaran IPA, sehingga berakibat mereka mengalami kesulitan di dalam mempelajari IPA dan pada akhirnya hasil belajar IPA pun rendah. Salah satu faktor rendahnya hasil belajar IPA adalah kemandirian belajar siswa.

Kemandirian belajar adalah kegiatan belajar aktif yang dibangun dengan bekal pengetahuan atau kompetensi yang dimiliki, baik dalam menetapkan waktu belajar, tempat belajar, cara belajar, maupun evaluasi belajar yang dilakukan oleh siswa sendiri. (Mujiman 2005). Kemandirian muncul ketika siswa menemukan diri pada posisi yang menuntut siswa untuk belajar tidak bergantung terhadap orang lain serta mempunyai kepercayaan diri yang tinggi. Karena siswa yang mandiri tidak akan bergantung pada orang lain, dan selalu berusaha menghadapi masalah-masalah yang terjadi di kehidupan nyata.

Kenyataan pada hasil wawancara pada tanggal 17 Januari 2017 di SDN Pajajaran Bogor di kelas IVA diperoleh informasi dari guru kelas IVA bahwa karakteristik siswa yang memiliki kemandirian belajar tinggi ada sekitar $40 \%$, sisanya $60 \%$ siswa yang memiliki kemandirian belajar rendah. Beberapa masalah yang berkaitan dengan kemandirian belajar dan hasil belajar Ilmu Pengetahuan Alam di kelas IVA yaitu seperti masih banyak siswa yang tidak berani untuk maju ke depan ketika di minta gurunya untuk mempresentasikan hasil pengamatan dan percobaan-percobaan Ilmu Pengetahuan Alam. Masing-masing siswa saling tunjukmenunjuk temannya untuk maju ke depan. Lalu masih ada siswa yang ketika diberi tugas mengerjakan soal-soal Ilmu Pengetahuan Alam yang berada di LKS masih bergantung pada jawaban teman sebelahnya, seperti siswa lebih memilih untuk menunggu temannya yang lain mengerjakan tugas terlebih dahulu untuk kemudian dicontek.

Sementara itu, hasil wawancara pada tanggal 18 Januari 2017 di kelas IVB SDN Pajajaran Bogor, diperoleh informasi dari Guru kelas IVB bahwa karakteristik siswa yang memiliki kemandirian belajar tinggi ada sekitar 53\%, sisanya $47 \%$ siswa yang memiliki kemandirian belajar rendah. Permasalahan yang berkaitan dengan kemandirian belajar dan hasil belajar Ilmu Pengetahuan Alam terlihat dari keaktifan siswanya di dalam proses pembelajaran, lalu dari hasil belajarnya, kemudian dari saat siswa mengerjakan LKS yang masih selalu bertanya kepada guru atau temannya, serta masih ada siswa yang masih perlu bantuan dari temannya di dalam menjawab soal-soal Ilmu Pengetahuan Alam di dalam LKS.

Berdasarkan hasil ulangan semester ganjil tahun ajaran 2016/2017 diperoleh informasi bahwa siswa kelas IVA dan IVB SDN Pajajaran Bogor menunjukkan sebagian besar masih belum mencapai KKM pada mata pelajaran Ilmu Pengetahuan Alam. Di kelas IVA yang belum mencapai KKM sekitar $50 \%$ atau 18 siswa dari jumlah seluruh siswa 36 siswa, dan yang sudah mencapai KKM sekitar 50\% atau 18 siswa. Sedangkan di kelas IVB yang belum mencapai KKM sekitar $32 \%$ atau 12 siswa dari jumlah seluruh siswa 38 siswa, dan yang sudah mencapai KKM sekitar $68 \%$ atau 26 siswa. Oleh karena itu, diperlukan proses pembelajaran yang menarik yang berpusat pada siswa, agar membantu mengembangkan kemandirian belajar siswa sehingga hasil belajarnya tercapai dengan baik seperti siswa akan mengalami perubahan yang terlihat dari 
kemampuannya,

pengetahuannya, keterampilannya, maupun sikapnya.

Berdasarkan permasalahan kemandirian belajar dan hasil belajar Ilmu Pengetahuan Alam yang ditemukan, peneliti tertarik melakukan penelitian untuk mengetahui ada atau tidak pengaruh kemandirian belajar siswa terhadap hasil belajar Ilmu Pengetahuan Alam siswa.

\section{MATERI DAN METODE}

Penelitian ini merupakan penelitian kuantitatif, dan termasuk metode penelitian korelasi fungsional. Penelitian ini bertujuan untuk mengetahui pengaruh dari kemandirian belajar terhadap hasil belajar IPA siswa kelas IV SD. Pada penelitian ini peneliti tidak memberikan perlakuan, peneliti hanya ingin mengetahui pengaruh dari variabel bebas $(X)$ terhadap variabel terikat (Y) dan nantinya diharapkan dapat mengubah kondisi siswa menjadi lebih baik. Rancangan untuk penelitian ini adalah dengan menyebar angket.

Penelitian ini dilaksanakan di kelas IV SD Negeri Pajajaran Kota Bogor. Waktu penelitian ini akan dilaksanakan selama dua bulan, terhitung dari bulan Januari hingga bulan Februari 2017.

Variabel bebas dalam penelitian ini yaitu kemandirian belajar yang disimbolkan dengan X. Dan variabel terikat dalam penelitian ini yaitu hasil belajar IPA yang disimbolkan dengan Y.

Definisi operasional kemandirian belajar yaitu perilaku siswa dalam belajar yang dilakukan atas dasar keinginan sendiri yang ditandai dengan kemampuan merencanakan, tanggung jawab, mengelola diri, serta inisiatif. Adapun tolak ukur yang digunakan adalah indikator dari kemandirian belajar siswa, yaitu: (1) kemampuan merencanakan yang ditandai dengan menetapkan tujuan pembelajaran dan cara belajar; (2) tanggung jawab yang ditandai dengan memiliki ketekunan dan berani memecahkan masalah; (3) mengelola diri yang ditandai dengan dapat menilai sendiri dengan apa yang dicapai dan dalam belajar tidak bergantung dengan orang lain; (4) inisiatif yang ditandai dengan memilih sumber belajar sendiri dan membuat jadwal belajar sendiri. Serta definisi operasional hasil belajar yaitu suatu proses atau usaha yang dilakukan seseorang setelah melakukan kegitan belajar. Hasil belajar meliputi ranah kognitif, afektif, maupun psikomotor yang diambil dari data penilaian guru. (1) Hasil belajar ranah kognitif berupa penilaian tes tertulis mengenai materi sifat-sifat cahaya yang terdiri dari indikator: a) mengidentifikasi sifat-sifat cahaya dan keterkaitannya dengan indera penglihatan dalam kehidupan seharihari, b) melaporkan hasil percobaan cakram warna yang memanfaatkan sifat-sifat cahaya dalam bentuk tulisan; (2) Hasil belajar ranah afektif berupa penilaian lembar pengamatan skala sikap yang terdiri dari penilaian aspek jujur, disiplin, percaya diri, dan kerja sama dalam waktu belajar mengenai materi sifatsifat cahaya. (3) Hasil belajar ranah psikomotor berupa penilaian lembar pengamatan yang berupa penilaian kinerja atau keterampilan dalam membuat percobaan cakram warna yang terdiri dari kriteria penilaian penerapan konsep, prosedur percobaan, strategi percobaan, dan kesimpulan percobaan.

Populasi dalam penelitian ini adalah siswa kelas IV SDN Pajajaran Bogor yang terdiri dari IVA dan IVB yang berjumlah 74 siswa. Dan sampel dalam penelitian ini yaitu 62 responden yang dihitung menggunakan rumus slovin dengan derajat kesalahan $5 \%$. Teknik pengambilan sampel dalam penelitian ini dilakukan dengan menggunakan teknik acak sederhana (simple random sampling). Teknik ini digunakan karena pengambilan sampelnya dilakukan secara acak, sehingga semua siswa bisa menjadi responden.

Teknik pengumpulan data merupakan tahap yang sangat pertama dilakukan dalam sebuah penelitian yang akan di teliti, dikarenakan tujuannya di dalam melakukan sebuah penelitian yang akan kita lakukan ialah mendapatkan data-data yang nyata. (Sugiyono 2015). Teknik pengumpulan data 
yang digunakan di dalam penelitian ini adalah: Pertama yaitu teknik wawancara. Teknik wawancara di dalam penelitian ini digunakan sebagai pengumpulan data awal sebelum penelitian berlangsung yaitu untuk mengetahui permasalahan yang terjadi di tempat penelitian, kegiatan belajar di tempat penelitian, dan hasil belajar di tempat penelitian. Narasumber meliputi guru kelas IVA dan IVB SDN Pajajaran Bogor.

Teknik kedua yaitu menggunakan angket atau kuesioner. Kuesioner ialah cara seperti membagikan kalimat-kalimat pernyataan tertulis kepada siswa-siswa di sekolah yang dijadikan penelitian. (Sugiyono 2015). Teknik ini ditujukan pada siswa kelas IVA dan IVB yang digunakan untuk mengetahui bagaimana kemandirian belajar siswa di SDN Pajajaran Bogor. Angket yang digunakan dibuat berdasarkan indikator-indikator yang diambil dari pengertian kemandirian dari beberapa ahli, dan berbentuk skala likert.

Teknik yang terakhir yaitu menggunakan teknik dokumentasi. Dokumentasi artinya bahan-bahan tertulis, seperti dokumen mengenai kondisi lingkungan sekolah, data guru, data peserta didik, organisasi sekolah, dan sebagainya (Arifin 2012). Dokumentasi digunakan untuk memperoleh data nilai ulangan (kognitif) semester 1 kelas IVA dan IVB sebagai salah satu sumber untuk mengetahui nilai kognitif siswa. Serta hasil belajar afektif dan psikomotorik yang diambil melalui lembar pengamatan di kelas IVA dan IVB SDN Pajajaran Bogor.

Instrumen dalam penelitian ini yaitu berupa angket tentang kemandirian belajar siswa yang didapat dari indikator-indikator yang diambil dari pengertian kemandirian belajar dari beberapa ahli. Uji coba pada penelitian ini dilakukan melalui dua tahap yaitu uji validitas dan uji reliabilitas. Untuk menguji validitas instrument menggunakan rumus korelasi Product Moment (Sudijono 2014). Kriteria yang ditetapkan yaitu jika rhitung > rtabel maka butir soal tersebut dinyatakan valid, sedangkan jika $r_{\text {hitung }}<r_{\text {tabel }}$ maka butir soal tersebut dinyatakan invalid. Butir soal yang dinyatakan valid apabila memiliki $r_{\text {hitung }}>r_{\text {tabel }}$ berdasarkan tabel nilai koefisien korelasi "r" Product Moment Pearson. Dan pada uji reliabilitas dalam penelitian ini menggunakan rumus Alpha Cronbach dengan bantuan program SPSS 16.0 for windows. Kriteria yang digunakan adalah jika nilai hitung alpha lebih besar ( $>$ ) dari nilai tabel $r$ maka angket dinyatakan reliabel. (Muhidin dan Abdurahman 2009).

Dalam penelitian ini, teknik analisis data meliputi analisis deskriptif. Analisis statistika deskriptif meliputi modus, ratarata (mean), standar deviasi, nilai maksimum, dan nilai minimum. Penyajian data pada analisis deskriptif ini menggunakan distribusi frekuensi, diagram batang dan lingkaran (Sugiyono 2015). Analisis deskriptif di dalam penelitian ini terdiri dari analisis skala sikap kemandirian belajar siswa serta analisis skala sikap hasil belajar siswa.

Sikap ialah sesuatu hal yang mendorong seseorang bertingkah laku ketika seseorang menyukai atau tidak menyukai sesuatu, baik itu hal positif maupun negatif (Azwar 2016). Di dalam penelitian ini instrumen dalam kemandirian belajar berupa pertanyaanpertanyaan yang berhubungan dengan indikator sikap dalam kemandirian belajar. Instrumen disusun dalam bentuk skala Likert dengan item angket sebanyak 20 soal yang diisi dengan cara memberi tanda $(\sqrt{ })$ pada jawaban dari beberapa alternatif jawaban yang sudah disediakan seperti SL jika selalu, SR jika sering, KD jika kadangkadang, dan TP jika tidak pernah. Masingmasing jawaban diberi nilai $\mathrm{SL}=4, \mathrm{SR}=3$, $\mathrm{KD}=2$, dan $\mathrm{TP}=1$. Analisis hasil skala sikap di dalam penelitian ini menggunakan lima kriteria yaitu:

Tabel 1 Kriteria sikap

\begin{tabular}{ll}
\hline Rerata Skor Sikap & Interpretasi \\
\hline$X \leq-1,5 \sigma$ & Sangat Rendah \\
$-1,5 \sigma<X \leq-0,5 \sigma$ & Rendah \\
$-0,5 \sigma<X \leq+0,5 \sigma$ & Sedang \\
$+0,5 \sigma<X \leq+1,5 \sigma$ & Tinggi \\
$+1,5 \sigma<X$ & Sangat Tinggi \\
\hline
\end{tabular}

Skala kemandirian belajar terdiri dari empat indikator di antaranya yaitu 
merencanakan pembelajaran, memiliki rasa tanggung jawab, mampu mengelola diri, dan memiliki inisiatif. Instrumen kemandirian belajar terdiri dari 20 item yang masingmasing itemnya diberi skor yang berkisar mulai dari 1, 2, 3, dan 4. Dengan demikian, skor terkecil yang mungkin diperoleh oleh subjek pada skala tersebut adalah $\mathrm{X}=20$ (yaitu 20x1) dan skor terbesar adalah $X=80$ (yaitu 20x4). Maka rentangan skor skala sebesar 80 (yaitu 80-0) itu dibagi dalam enam satuan deviasi standar sehingga diperoleh $80 / 6=13,3$. Angka 13,3 ini merupakan estimasi besarnya satuan deviasi standar populasi $(\sigma)$ yang kita gunakan untuk membuat kategori normatif skor subjek sehingga akan didapatkan kategori atau kriteria sikap seperti pada Tabel 2 .

Tabel 2 Kriteria sikap kemandirian belajar

\begin{tabular}{ll}
\hline Rerata Skor Sikap & Interpretasi \\
\hline$X \leq 19,95$ & Sangat Rendah \\
$19,95<X \leq 33,25$ & Rendah \\
$33,25<X \leq 46,55$ & Sedang \\
$46,55<X \leq 59,85$ & Tinggi \\
$59,85<X$ & Sangat Tinggi \\
\hline
\end{tabular}

Gambar 1 menunjukkan rentangan skor skala sikap siswa beserta kriterianya pada seluruh aspek indikator kemandirian belajar.

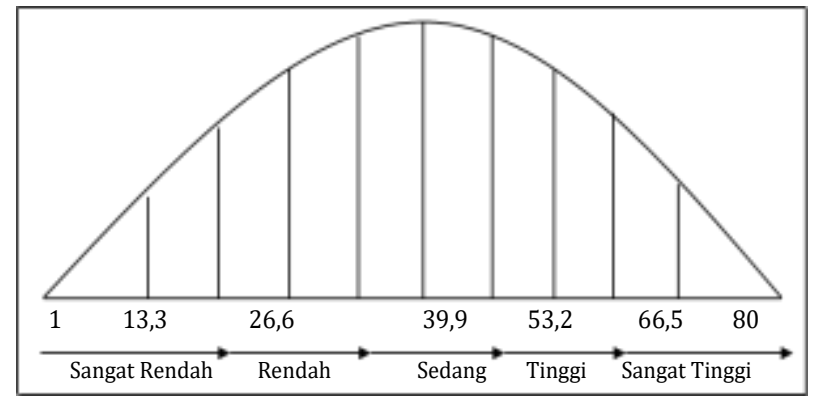

Gambar 1 Rentangan skor skala sikap kemandirian belajar

Adapun cara pengolahan data untuk masing-masing indikator sikap kemandirian belajar adalah sebagai berikut.

a. Indikator sikap merencanakan pembelajaran terdiri atas 6 item yang masing-masing itemnya diberi skor yang berkisar mulai dari 1, 2, 3, dan 4. Dengan demikian, skor terkecil yang mungkin diperoleh oleh subjek pada skala tersebut adalah $\mathrm{X}=6$ (yaitu $6 \times 1$ ) dan skor terbesar adalah $\mathrm{X}=24$ (yaitu 6x4). Maka rentangan skor skala sebesar 24 (yaitu 24-0) itu dibagi dalam enam satuan deviasi standar sehingga diperoleh 24/6 $=4$. Angka 4 ini merupakan estimasi besarnya satuan deviasi standar populasi $(\sigma)$ yang kita gunakan untuk membuat kategori normatif skor subjek sehingga akan didapatkan kriteria sikap seperti pada Tabel 3.

Tabel 3 Kriteria sikap indikator merencanakan pembelajaran

\begin{tabular}{ll}
\hline Rerata Skor Sikap & Interpretasi \\
\hline $\mathrm{X} \leq 6$ & Sangat Rendah \\
$6<\mathrm{X} \leq 10$ & Rendah \\
$10<\mathrm{X} \leq 14$ & Sedang \\
$14<\mathrm{X} \leq 18$ & Tinggi \\
$18<\mathrm{X}$ & Sangat Tinggi \\
\hline
\end{tabular}

Gambar 2 menunjukkan rentangan skor skala sikap siswa beserta kriterianya pada indikator merencanakan pembelajaran.

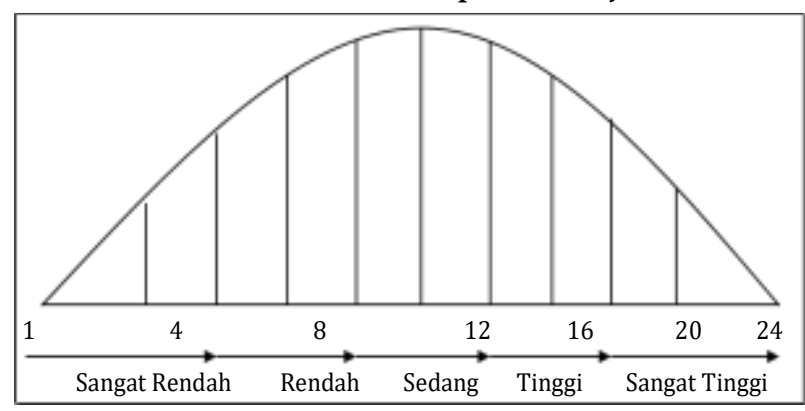

Gambar 2 Rentangan skor skala sikap indikator merencanakan pembelajaran

b. Indikator sikap memiliki rasa tanggung jawab terdiri atas 5 item yang masingmasing itemnya diberi skor yang berkisar mulai dari 1, 2, 3, dan 4. Dengan demikian, skor terkecil yang mungkin diperoleh oleh subjek pada skala tersebut adalah $\mathrm{X}$ $=5$ (yaitu $5 \times 1$ ) dan skor terbesar adalah $X=20$ (yaitu $5 x 4$ ). Maka rentangan skor skala sebesar 20 (yaitu 20-0) itu dibagi dalam enam satuan deviasi standar sehingga diperoleh 20/6 = 3,3. Angka 3,3 ini merupakan estimasi besarnya satuan 
deviasi standar populasi $(\sigma)$ yang kita gunakan untuk membuat kategori normatif skor subjek sehingga akan didapatkan kriteria sikap seperti pada Tabel 4.

Tabel 4 Kriteria sikap memiliki rasa tanggung jawab

\begin{tabular}{ll}
\hline Rerata Skor Sikap & Interpretasi \\
\hline$X \leq 4,95$ & Sangat Rendah \\
$4,95<X \leq 8,25$ & Rendah \\
$8,25<X \leq 11,55$ & Sedang \\
$11,55<X \leq 14,85$ & Tinggi \\
$14,85<X$ & Sangat Tinggi \\
\hline
\end{tabular}

Gambar 3 menunjukkan rentangan skor skala sikap siswa beserta kriterianya pada indikator memiliki rasa tanggung jawab.

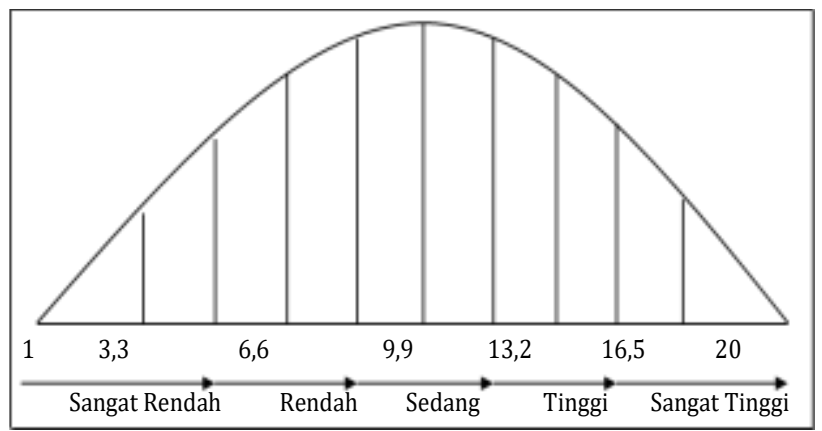

Gambar 3 Rentangan skor skala sikap indikator memiliki rasa tanggung jawab

c. Indikator sikap mampu mengelola diri terdiri atas 5 item yang masing-masing itemnya diberi skor yang berkisar mulai dari 1, 2, 3, dan 4. Dengan demikian, skor terkecil yang mungkin diperoleh oleh subjek pada skala tersebut adalah $\mathrm{X}=5$ (5x1) dan skor terbesar adalah $X=20$ (5x4). Maka rentangan skor skala sebesar 20 (20-0) itu dibagi dalam enam satuan deviasi standar sehingga diperoleh $20 / 6=3,3$. Angka 3,3 ini yang kita gunakan untuk membuat kategori normatif skor subjek. Sehingga akan didapatkan kriteria sikap seperti yang terdapat pada Tabel 5.

Tabel 5 Kriteria sikap mampu mengelola diri

\begin{tabular}{ll}
\hline Rerata Skor Sikap & Interpretasi \\
\hline$X \leq 4,95$ & Sangat Rendah \\
$4,95<X \leq 8,25$ & Rendah \\
$8,25<X \leq 11,55$ & Sedang \\
$11,55<X \leq 14,85$ & Tinggi \\
$14,85<X$ & Sangat Tinggi \\
\hline
\end{tabular}

Gambar 4 menunjukkan rentangan skor skala sikap siswa beserta kriterianta pada indikator mampu mengelola diri.

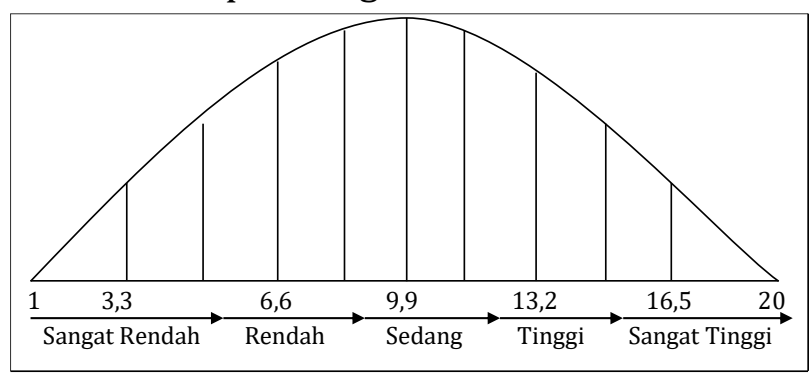

Gambar 4 Rentangan skor skala sikap indikator mampu mengelola diri

d. Indikator sikap memiliki inisiatif terdiri atas 4 item yang masing-masing itemnya diberi skor yang berkisar mulai dari 1, 2, 3, dan 4. Dengan demikian, skor terkecil yang mungkin diperoleh oleh subjek pada skala tersebut adalah $\mathrm{X}=4$ (yaitu $4 \times 1$ ) dan skor terbesar adalah $X=16$ (yaitu 4x4). Maka rentangan skor skala sebesar 16 (yaitu 16-0) itu dibagi dalam enam satuan deviasi standar sehingga diperoleh $16 / 6=2,6$. Angka 2,6 ini merupakan estimasi besarnya satuan deviasi standar populasi $(\sigma)$ yang kita gunakan untuk membuat kategori normatif skor subjek sehingga akan didapatkan kriteria sikap seperti pada Tabel 6.

Tabel 6 Kriteria sikap memiliki inisiatif

\begin{tabular}{ll}
\hline Rerata Skor Sikap & Interpretasi \\
\hline$X \leq 3,9$ & Sangat Rendah \\
$3,9<X \leq 6,5$ & Rendah \\
$6,5<X \leq 9,1$ & Sedang \\
$9,1<X \leq 11,7$ & Tinggi \\
$11,7<X$ & Sangat Tinggi \\
\hline
\end{tabular}


Gambar 5 menunjukkan rentangan skor skala sikap siswa beserta kriterianya pada indikator memiliki inisiatif.

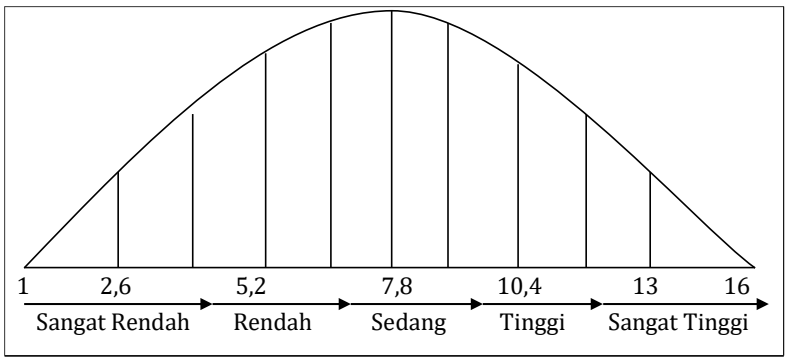

Gambar 5 Rentangan skor skala sikap indikator memiliki inisiatif

Selanjutnya analisis skala hasil belajar siswa. Adapun langkah-langkah untuk menentukan tolak ukur kriteria penilaian hasil belajar ranah kognitif sebagai berikut.

a. Hasil belajar ranah kognitif di dapat dari dokumentasi data guru yang berupa penilaian tes tertulis mengenai materi sifat-sifat cahaya yang terdiri dari indikator: a) mengidentifikasi sifat-sifat cahaya dan keterkaitannya dengan indera penglihatan dalam kehidupan sehari-hari, b) melaporkan hasil percobaan cakram warna yang memanfaatkan sifat-sifat cahaya dalam bentuk tulisan. Tolak ukur kriteria penilaian ialah dengan menggunakan kriteria kurang, cukup, dan baik. Adapun langkah-langkah untuk menentukan tolak ukur kriteria penilaian hasil belajar ranah kognitif terdapat pada Tabel 7.

Tabel 7 Cara mengkriteriakan hasil belajar kognitif

\begin{tabular}{lll}
\hline Kriteria & Cara & Ket \\
Penilaian & Mengkriteriakan & \\
\hline Kurang & $X<(\mu-\sigma)$ & $\mu$ : Mean \\
& $X<(73,81-8,56)$ & $\sigma \quad$ \\
& $X<65$ & Standar \\
Sedang & $(\mu-\sigma) \leq X<(\mu+\sigma)$ & Deviation \\
& $(73,81-8,56) \leq X<$ & \\
& $(73,81+8,56)$ & \\
Tinggi & $65 \leq X<82$ & \\
& $X \geq(\mu+\sigma)$ & \\
& $X \geq(73,81+8,56)$ & \\
& $X \geq 82$ &
\end{tabular}

Sehingga akan didapatkan kriteria hasil belajar kognitif seperti pada Tabel 8 .

Tabel 8 Kriteria hasil belajar kognitif

\begin{tabular}{ll}
\hline Rerata Nilai Hasil Belajar & Interpretasi \\
\hline $\mathrm{X}<65$ & Kurang \\
$65 \leq \mathrm{X}<82$ & Cukup \\
$\mathrm{X} \geq 82$ & Baik \\
\hline
\end{tabular}

Gambar 6 menunjukkan rentangan skor hasil belajar kognitif.

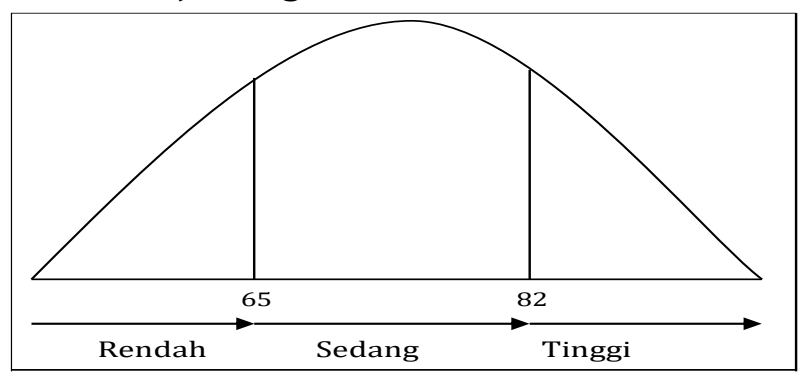

Gambar 6 Rentangan skor kognitif

b. Hasil belajar ranah afektif di dapat dari dokumentasi data guru yang berupa penilaian lembar pengamatan skala sikap yang teridiri dari penilaian aspek jujur, disiplin, percaya diri, dan kerja sama dalam waktu belajar mengenai materi sifat-sifat cahaya. Tolak ukur kriteria penilaian ialah dengan menggunakan kriteria kurang, cukup, dan baik. Adapun langkah-langkah untuk menentukan tolak ukur kriteria penilaian hasil belajar ranah afektif terdapat pada Tabel 9.

Tabel 9 Cara mengkriteriakan hasil belajar afektif

\begin{tabular}{lll}
\hline Kriteria & Cara & Ket \\
Penilaian & Mengkriteriakan & \\
\hline Kurang & $X<(\mu-\sigma)$ & $\mu$ : Mean \\
& $X<(79,66-10,95)$ & $\sigma$ \\
& $X<69$ & Standar \\
Sedang & $(\mu-\sigma) \leq X<(\mu+\sigma)$ & Deviation \\
& $(79,66-10,95) \leq X$ & \\
& $<(79,66+10,95)$ & \\
Tinggi & $69 \leq X<91$ & \\
& $X \geq(\mu+\sigma)$ & \\
& $X \geq(79,66+10,95)$ & \\
& $X \geq 91$
\end{tabular}


Sehingga akan didapatkan kriteria hasil belajar afektif seperti pada Tabel 10 .

Tabel 10 Kriteria hasil belajar afektif

\begin{tabular}{ll}
\hline Rerata Nilai Hasil Belajar & Interpretasi \\
\hline$X<69$ & Kurang \\
$69 \leq X<91$ & Cukup \\
$X \geq 91$ & Baik \\
\hline
\end{tabular}

Gambar 7 menunjukkan rentangan skor hasil belajar afektif.

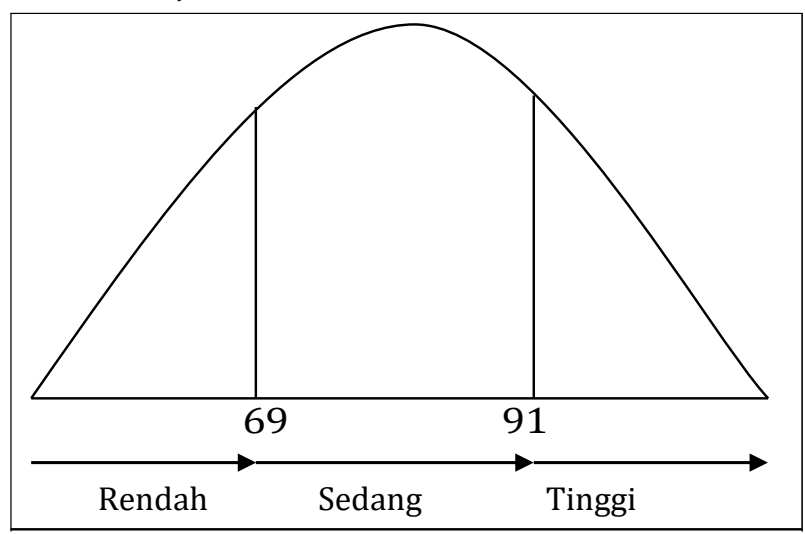

Gambar 7 Rentangan skor afektif

c. Hasil belajar ranah psikomotor di dapat dari dokumentasi data guru yang berupa penilaian lembar pengamatan yang berupa penilaian kinerja atau keterampilan dalam membuat percobaan cakram warna yang terdiri dari kriteria penilaian penerapan konsep, prosedur percobaan, strategi percobaan, dan kesimpulan percobaan. Tolak ukur kriteria penilaian ialah dengan menggunakan kriteria kurang, cukup, dan baik. Adapun langkah-langkah untuk menentukan tolak ukur kriteria penilaian hasil belajar ranah psikomotor seperti pada Tabel 11, sehingga akan didapatkan kriteria hasil belajar psikomotor seperti pada Tabel 12. Adapun rentangan skor hasil belajar psikomotor dapat dilihat pada Gambar 8.

Uji prasyarat analisis meliputi uji normalitas dan uji linearitas. Uji Normalitas dilakukan untuk mengetahui apakah data dalam penelitian berdistribusi normal atau tidak. Uji normalitas dilakukan pada kedua variabel yang akan diteliti, yaitu variabel bebas (X) kemandirian belajar dan variabel terikat (Y) hasil belajar IPA dengan menggunakan uji Kolmogrov-Smirnov dengan bantuan Program SPSS16.0 for windows. Sebaran data dikatakan normal jika nilai signifikansi lebih besar dari 0,05 (sig > 0,05) (Sugiyono 2012).

Tabel 11 Cara mengkriteriakan hasil belajar psikomotor

\begin{tabular}{|c|c|c|}
\hline $\begin{array}{l}\text { Kriteria } \\
\text { Penilaian }\end{array}$ & $\begin{array}{l}\text { Cara } \\
\text { Mengkriteriakan }\end{array}$ & Ket \\
\hline \multirow[t]{3}{*}{ Kurang } & $X<(\mu-\sigma)$ & $\mu:$ Mean \\
\hline & $\begin{array}{l}X<(76,63 \\
10,58)\end{array}$ & $\begin{array}{l}\sigma: \text { Standar } \\
\text { Deviation }\end{array}$ \\
\hline & $X<66$ & \\
\hline \multirow[t]{3}{*}{ Sedang } & $(\mu-\sigma) \leq X<(\mu+\sigma$ & \\
\hline & $\begin{array}{l}(76,63-10,58) \\
X<(76,63 \\
10,58)\end{array}$ & \\
\hline & $66 \leq X<87$ & \\
\hline \multirow[t]{3}{*}{ Tinggi } & $X \geq(\mu+\sigma)$ & \\
\hline & $\begin{array}{l}X \geq(76,63 \\
10,58)\end{array}$ & \\
\hline & $X \geq 87$ & \\
\hline
\end{tabular}

Tabel 12 Kriteria hasil belajar psikomotor

\begin{tabular}{ll}
\hline Rerata Nilai Hasil Belajar & Interpretasi \\
\hline$X<66$ & Kurang \\
$66 \leq X<87$ & Cukup \\
$X \geq 87$ & Baik \\
\hline
\end{tabular}

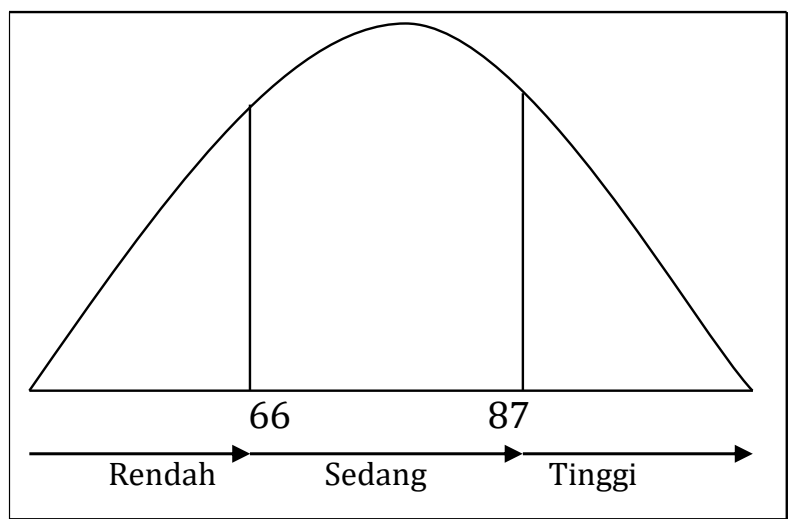

Gambar 8 Rentangan skor psikomotor

Setelah data di uji normalitas, kemudian data di uji linieritas. Uji linieritas yang dimaksud adalah suatu prosedur yang digunakan untuk mengetahui hubungan 
linier atau tidaknya antara variabel bebas dan variabel terikat. Uji lineritas dilakukan dengan menggunakan bantuan program komputer SPSS 16.0 for windows. Untuk mengetahui hubungan antar variabel linier atau tidak dapat dilakukan memperhatikan nilai signifikansinya, jika nilai signifikansi > 0,05 maka hubungan antar variabel dikatakan linier (Sugiyono 2012).

Teknik analisis data meliputi persamaan regresi, koefisien determinasi, dan uji signifikansi yang melalui uji t. persamaan regresi digunakan untuk mengembangkan suatu persamaan untuk meramalkan sesutu variabel dari variabel kedua yang telah diketahui. Selanjutnya koefisien determinasi digunakan untuk mengetahui seberapa besar variabel bebas mempengaruhi variabel terikat, sedangkan sisanya dipengaruhi variabel lain. Dan yang terakhir data di uji signifikansi dengan melalui uji $t$, uji $t$ digunakan untuk membuktikan signifikansi apakah ada atau tidaknya pengaruh antara variabel bebas $(\mathrm{X})$ terhadap variabel tidak bebas (Y), dengan syarat bila t hitung lebih besar dari t tabel serta jika signifikasi lebih kecil dari 0,05 maka data signifikansi.

\section{HASIL DAN PEMBAHASAN}

\section{Hasil}

\section{Variabel X Kemandirian Belajar}

Pengambilan data dilakukan dengan menggunakan skala kemandirian belajar dan untuk hasil belajar IPA berupa penilaian kognitif dari hasil penilaian tes tertulis, afektif dan psikomotor melalui lembar pengamatan pada pembelajaran IPA materi sifat-sifat cahaya.

Dari hasil angket atau kuesioner yang digunakan dalam teknik pengumpulan data, maka diperoleh hasil penelitian kemandirian belajar dari sampel 62 siswa yang bisa dilihat pada Tabel 13.

Berdasarkan Tabel 13 terlihat bahwa skor maksimal diperoleh sebesar 80, dan skor minimal diperoleh sebesar 38. Adapun tabelnya dapat dilihat pada tabel 14 .
Tabel 13 Deskriptif statistik kemandirian belajar

\begin{tabular}{lr}
\hline & \multicolumn{1}{c}{ Skor } \\
\hline $\mathrm{N}$ & 62 \\
Mean & 60,71 \\
Standar Deviation & 9,18 \\
Minimum & 38,00 \\
Maximum & 80,00 \\
\hline
\end{tabular}

Tabel 14 Distribusi frekuensi kemandirian belajar

\begin{tabular}{llrr}
\hline No & $\begin{array}{c}\text { Kelas } \\
\text { Interval }\end{array}$ & Frekuensi & $\begin{array}{c}\text { Nilai } \\
\text { Titik } \\
\text { Tengah }\end{array}$ \\
\hline 1 & $38-43$ & 3 & 40,5 \\
2 & $44-49$ & 2 & 46,5 \\
3 & $50-55$ & 10 & 52,5 \\
4 & $56-61$ & 21 & 58,5 \\
5 & $62-67$ & 10 & 64,5 \\
6 & $68-73$ & 8 & 70,5 \\
7 & $74-80$ & 8 & 76,5 \\
Jml & & 62 & \\
\hline
\end{tabular}

Berdasarkan tabel 14 dapat disimpulkan interval yang paling tinggi frekuensinya berada di kelas interval 56-61, dan frekuensi yang paling rendah berada di kelas interval 44-49. Selanjutnya, dapat dilihat diagram frekuensi kemandirian belajar pada Gambar 9.

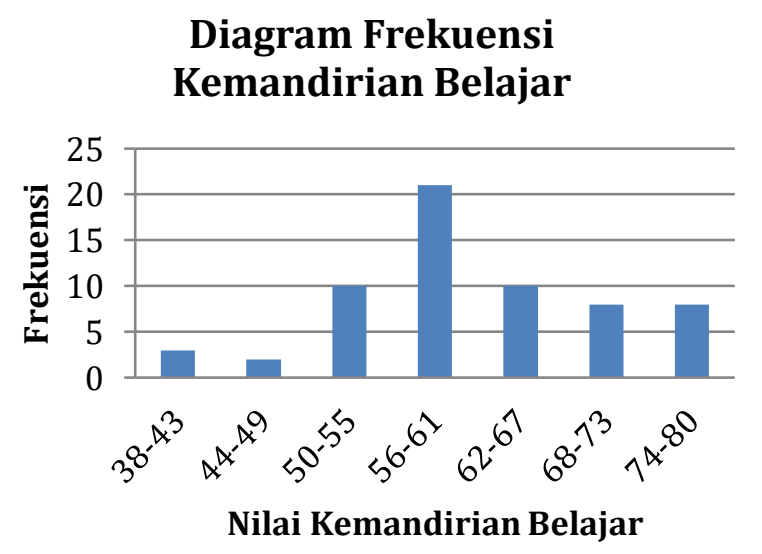

Gambar 9 Diagram frekuensi kemandirian belajar 
Berdasarkan Gambar 9 dapat disimpulkan bahwa skor tertinggi berada pada interval 56-51 yang berjumlah 21 siswa dan sebaliknya skor terendah berada pada interval 44-49 yang berjumlah 2 siswa.
Berdasarkan data kemandirian belajar tersebut, dapat dilihat kriteria penilaian kemandirian belajar dengan kriteria sangat rendah, rendah, sedang, tinggi, dan sangat tinggi pada Tabel 15.

Tabel 15 Kriteria penilaian kemandirian belajar

\begin{tabular}{|c|c|c|c|}
\hline Skala (Interval) & Kriteria & Frekuensi & Persentase \\
\hline$X \leq 19,95$ & Sangat Rendah & 0 & $0 \%$ \\
\hline $19,95<X \leq 33,25$ & Rendah & 0 & $0 \%$ \\
\hline $33,25<X \leq 46,55$ & Sedang & 4 & $6 \%$ \\
\hline $46,55<X \leq 59,85$ & Tinggi & 24 & $39 \%$ \\
\hline \multirow[t]{2}{*}{$59,85<X$} & Sangat Tinggi & 34 & $55 \%$ \\
\hline & Jumlah & 62 & $100 \%$ \\
\hline
\end{tabular}

Berdasarkan Tabel 15 setelah ditetapkan norma kriterisasi seperti di atas, maka seseorang yang mendapat skor $\mathrm{X}=80$ dalam Skala Kemandirian Belajar tersebut dapat didiagnosis sebagai memiliki kemandirian belajar yang tinggi, dan sebaliknya seseorang yang memiliki skor $\mathrm{X}=38$ dapat didiagnosis sebagai memiliki kemandirian belajar yang rendah. Serta kriteria penilaian kemandirian belajar siswa 4 siswa (6\%) mendapatkan kriteria sedang, 24 siswa (39\%) mendapatkan kriteria tinggi, dan 34 siswa (55\%) mendapatkan kriteria sangat tinggi. Maka dapat disimpulkan bahwa kecenderungan hasil kemandirian belajar siswa berada pada kriteria sangat tinggi. Adapun hasil pengelohan data kriteria penilaian kemandirian masing-masing indikator terdapat pada Tabel 16.

Tabel 16 Kriteria penilaian indikator merencanakan pembelajaran

\begin{tabular}{llrr}
\hline \multicolumn{1}{c}{ Skala (Interval) } & \multicolumn{1}{c}{ Kriteria } & Frekuensi & Persentase \\
\hline $\mathrm{X} \leq 6$ & Sangat Rendah & 0 & $0 \%$ \\
$6<\mathrm{X} \leq 10$ & Rendah & 0 & $0 \%$ \\
$10<\mathrm{X} \leq 14$ & Sedang & 4 & $7 \%$ \\
$14<\mathrm{X} \leq 18$ & Tinggi & 25 & $40 \%$ \\
$18<\mathrm{X}$ & Sangat Tinggi & 33 & $53 \%$ \\
& Jumlah & 62 & $100 \%$ \\
\hline
\end{tabular}

Berdasarkan Tabel 16 terlihat bahwa kriteria penilaian kemandirian belajar dengan indikator merencanakan pembelajaran siswa yaitu 0 siswa $(0 \%)$ mendapatkan kriteria sangat rendah, 0 siswa (0\%) mendapatkan kriteria rendah, 4 siswa (7\%) mendapatkan kriteria sedang, 25 siswa (40\%) mendapatkan kriteria tinggi, dan 33 siswa (53\%) mendapatkan kriteria sangat tinggi.
Berdasarkan Tabel 17 terlihat bahwa kriteria penilaian kemandirian belajar siswa dengan indikator memiliki rasa tanggung jawab yaitu 0 siswa (0\%) mendapatkan kriteria sangat rendah. 0 siswa $(0 \%)$ mendapatkan kriteria rendah, 7 siswa (11\%) mendapatkan kriteria sedang, 21 siswa (34\%) mendapatkan kriteria tinggi, dan 34 siswa (55\%) mendapatkan kriteria sangat tinggi. 
Tabel 17 Kriteria penilaian indikator memiliki rasa tanggung jawab

\begin{tabular}{llrr}
\hline \multicolumn{1}{c}{ Skala (Interval) } & \multicolumn{1}{c}{ Kriteria } & Frekuensi & Persentase \\
\hline $\mathrm{X} \leq 4,95$ & Sangat Rendah & 0 & $0 \%$ \\
$4,95<\mathrm{X} \leq 8,25$ & Rendah & 0 & $0 \%$ \\
$8,25<\mathrm{X} \leq 11,55$ & Sedang & 7 & $11 \%$ \\
$11,55<\mathrm{X} \leq 14,85$ & Tinggi & 21 & $34 \%$ \\
$14,85<\mathrm{X}$ & Sangat Tinggi & 34 & $55 \%$ \\
& Jumlah & 62 & $100 \%$ \\
\hline
\end{tabular}

Tabel 18 Kriteria penilaian indikator mampu mengelola diri

\begin{tabular}{llrr}
\hline \multicolumn{1}{c}{ Skala (Interval) } & \multicolumn{1}{c}{ Kriteria } & Frekuensi & Persentase \\
\hline $\mathrm{X} \leq 4,95$ & Sangat Rendah & 0 & $0 \%$ \\
$4,95<\mathrm{X} \leq 8,25$ & Rendah & 0 & $0 \%$ \\
$8,25<\mathrm{X} \leq 11,55$ & Sedang & 11 & $18 \%$ \\
$11,55<\mathrm{X} \leq 14,85$ & Tinggi & 16 & $26 \%$ \\
$14,85<\mathrm{X}$ & Sangat Tinggi & 35 & $56 \%$ \\
& Jumlah & 62 & $100 \%$ \\
\hline
\end{tabular}

Berdasarkan Tabel 18 terlihat bahwa kriteria penilaian kemandirian belajar siswa dengan indikator mampu mengelola diri yaitu 0 siswa (0\%) mendapatkan kriteria sangat rendah, 0 siswa (0\%) mendapatkan kriteria rendah, 11 siswa (18\%) mendapatkan kriteria sedang, 16 siswa (26\%) mendapatkan kriteria tinggi, dan 35 siswa (56\%) mendapatkan kriteria sangat tinggi.

Tabel 19 Kriteria penilaian indikator memiliki inisiatif

\begin{tabular}{llrr}
\hline \multicolumn{1}{c}{ Skala (Interval) } & \multicolumn{1}{c}{ Kriteria } & Frekuensi & Persentase \\
\hline $\mathrm{X} \leq 3,9$ & Sangat Rendah & 0 & $0 \%$ \\
$3,9<\mathrm{X} \leq 6,5$ & Rendah & 0 & $0 \%$ \\
$6,5<\mathrm{X} \leq 9,1$ & Sedang & 7 & $11 \%$ \\
$9,1<\mathrm{X} \leq 11,7$ & Tinggi & 14 & $23 \%$ \\
$11,7<\mathrm{X}$ & Sangat Tinggi & 41 & $66 \%$ \\
& Jumlah & 62 & $100 \%$ \\
\hline
\end{tabular}

Berdasarkan Tabel 19 terlihat bahwa kriteria penilaian kemandirian belajar siswa dengan indikator memiliki inisiatif yaitu 0 siswa (0\%) mendapatkan kriteria sangat rendah, 0 siswa (0\%) mendapatkan kriteria rendah, 7 siswa (11\%) mendapatkan kriteria sedang, 14 siswa (23\%) mendapatkan kriteria tinggi, dan 41 siswa (66\%) mendapatkan kriteria sangat tinggi.

\section{Variabel Y Hasil Belajar}

Data dalam hasil belajar IPA diambil dari penilaian kognitif berupa penilaian tes tertulis mengenai materi sifat-sifat cahaya, hasil penilaian afektif dan hasil penilaian psikomotor yang diambil dari penilaian lembar pengamatan siswa kelas IV SDN Pajajaran Bogor sebanyak 62 siswa. 


\section{Hasil Belajar Aspek Kognitif}

Dari hasil dokumentasi yang digunakan dalam teknik pengumpulan data, hasil belajar IPA pada aspek kognitif yaitu berupa penilaian tes tertulis mengenai materi sifatsifat cahaya yang terdiri dari indikator: a) mengidentifiasi sifat-sifat cahaya dan keterkaitannya dengan indera penglihatan dalam kehidupan sehari-hari, b) melaporkan hasil percobaan cakram warna yang memanfaatkan sifat-sifat cahaya dalam bentuk tulisan, maka diperoleh hasil dari aspek kognitif yang bisa dilihat pada Tabel 19.

Tabel 20 Deskriptif statistik hasil belajar aspek kognitif

\begin{tabular}{lr}
\hline & \multicolumn{1}{c}{ Skor } \\
\hline $\mathrm{N}$ & 62 \\
Mean & 73,81 \\
Standar Deviation & 8,56 \\
Minimum & 63,00 \\
Maximum & 89,00 \\
\hline
\end{tabular}

Berdasarkan Tabel 20 terlihat bahwa nilai maksimal diperoleh sebesar 89, dan nilai minimal diperoleh sebesar 63. Selanjutnya, dapat dilihat diagram frekuensi hasil belajar pada Gambar 10.

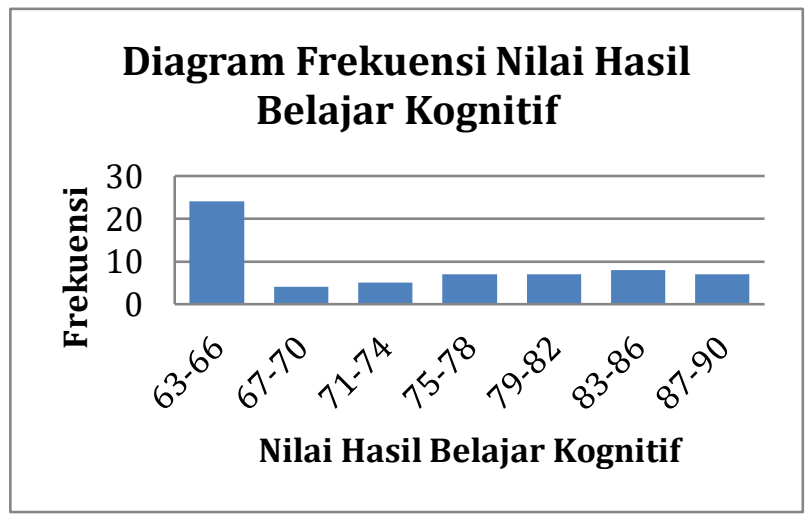

Gambar 10 Diagram frekuensi hasil belajar kognitif

Berdasarkan Gambar 10 dapat disimpulkan bahwa nilai tertinggi berada pada interval 63-66 yang berjumlah 24 siswa dan sebaliknya nilai terendah berada pada interval 67-70 yang berjumlah 4 siswa.
Berdasarkan data hasil belajar kognitif tersebut, dapat dilihat kriteria penilaian hasil belajar kognitif dengan kriteria kurang, cukup, dan baik pada Tabel 21.

Tabel 21 Kriteria penilaian hasil belajar kognitif

\begin{tabular}{llrr}
\hline $\begin{array}{c}\text { Skala } \\
\text { Interval) }\end{array}$ & Kriteria & Frekuensi & Persentase \\
\hline $\mathrm{X}<65$ & Kurang & 5 & $8 \%$ \\
$65 \leq \mathrm{X}<$ & Cukup & 41 & $66 \%$ \\
82 & & & \\
$X \geq 82$ & Baik & 16 & $26 \%$ \\
& Jumlah & 62 & $100 \%$ \\
\hline
\end{tabular}

Berdasarkan Tabel 21 terlihat bahwa kriteria penilaian hasil belajar kognitif siswa 5 siswa (8\%) mendapatkan kriteria kurang, 41 siswa (66\%) mendapatkan kriteria cukup, dan 16 siswa (26\%) mendapatkan kriteria baik. Maka dapat disimpulkan bahwa kecenderungan hasil kemandirian belajar siswa berada pada kriteria sangat tinggi.

\section{Hasil Belajar Aspek Afektif}

Dari hasil dokumentasi yang digunakan dalam teknik pengumpulan data, hasil belajar aspek afektif yaitu berupa penilaian lembar pengamatan skala sikap yang terdiri dari penilaian aspek jujur, disiplin, percaya diri, dan kerja sama dalam waktu belajar mengenai materi sifat-sifat cahaya, maka diperoleh hasil dari aspek afektif yang bisa dilihat pada Tabel 22.

Tabel 22 Deskriptif statistik hasil belajar aspek kognitif

\begin{tabular}{lr}
\hline & \multicolumn{1}{c}{ Skor } \\
\hline $\mathrm{N}$ & 62 \\
Mean & 79,66 \\
Standar Deviation & 10,95 \\
Minimum & 62,00 \\
Maximum & 100,00 \\
\hline
\end{tabular}

Berdasarkan Tabel 22 terlihat bahwa nilai maksimal diperoleh sebesar 100, dan nilai minimal diperoleh sebesar 62. Selanjutnya, 
dapat dilihat diagram frekuensi hasil belajar pada Gambar 11.

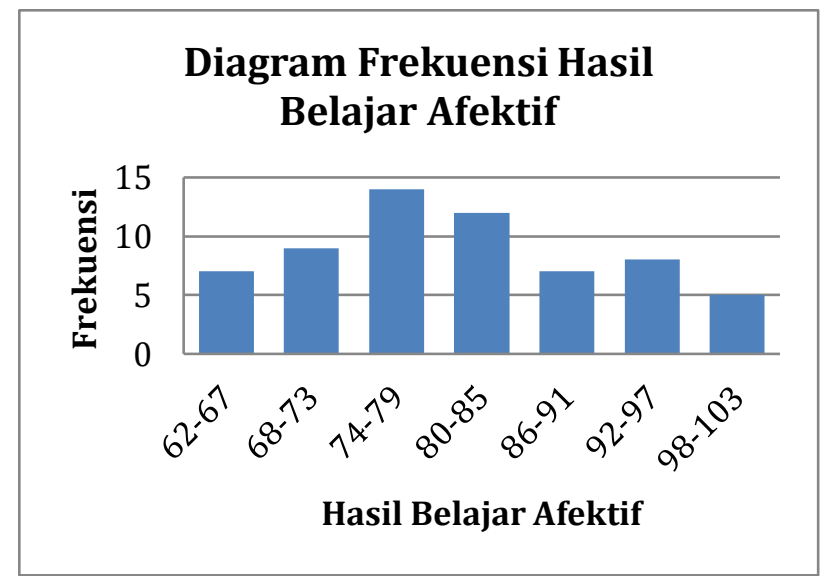

Gambar 11 Diagram frekuensi hasil belajar afektif

Berdasarkan Gambar 11 dapat disimpulkan bahwa nilai tertinggi berada pada interval 74-79 yang berjumlah 14 siswa dan sebaliknya nilai terendah berada pada interval 98-103 yang berjumlah 5 siswa.

Berdasarkan data hasil belajar afektif tersebut, dapat dilihat kriteria penilaian hasil belajar afektif dengan kriteria kurang, cukup, dan baik pada Tabel 23 .

Tabel 23 Kriteria penilaian hasil belajar afektif

\begin{tabular}{llrr}
\hline $\begin{array}{c}\text { Skala } \\
\text { (Interval) }\end{array}$ & Kriteria & Frekuensi & Persentase \\
\hline $\mathrm{X}<68$ & Kurang & 9 & $14 \%$ \\
$68 \leq \mathrm{X}<$ & Cukup & 40 & $64 \%$ \\
90 & & & \\
$\mathrm{X} \geq 90$ & Baik & 13 & $22 \%$ \\
& Jumlah & 62 & $100 \%$ \\
\hline
\end{tabular}

Berdasarkan Tabel 23 terlihat bahwa kriteria penilaian hasil belajar afektif siswa 9 siswa (14\%) mendapatkan kriteria kurang, 40 siswa (64\%) mendapatkan kriteria cukup, dan 13 siswa (22\%) mendapatkan kriteria baik. Maka dapat disimpulkan bahwa kecenderungan hasil kemandirian belajar siswa berada pada kriteria sangat tinggi.

\section{Hasil Belajar Aspek Psikomotor}

Dari hasil dokumentasi yang digunakan dalam teknik pengumpulan data, hasil belajar aspek psikomotor yaitu berupa lembar pengamatan psikomotor yang diperoleh dari guru kelas IVA dan IVB SDN Pajajaran Bogor. Lembar penilaian psikomotor terdiri dari kriteria penilaian: penerapan konsep, prosedur, strategi, dan kesimpulan dari percobaan. Hasil dari aspek psikomotor yang bisa dilihat pada Tabel 24 .

Tabel 24 Deskriptif statistik hasil belajar aspek psikomotor

\begin{tabular}{lr}
\hline & \multicolumn{1}{c}{ Skor } \\
\hline $\mathrm{N}$ & 62 \\
Mean & 76,63 \\
Standar Deviation & 10,58 \\
Minimum & 56,00 \\
Maximum & 100,00 \\
\hline
\end{tabular}

Berdasarkan Tabel 24 terlihat bahwa nilai maksimal diperoleh sebesar 100 , dan nilai minimal diperoleh sebesar 56. Selanjutnya, dapat dilihat diagram frekuensi hasil belajar pada Gambar 12.

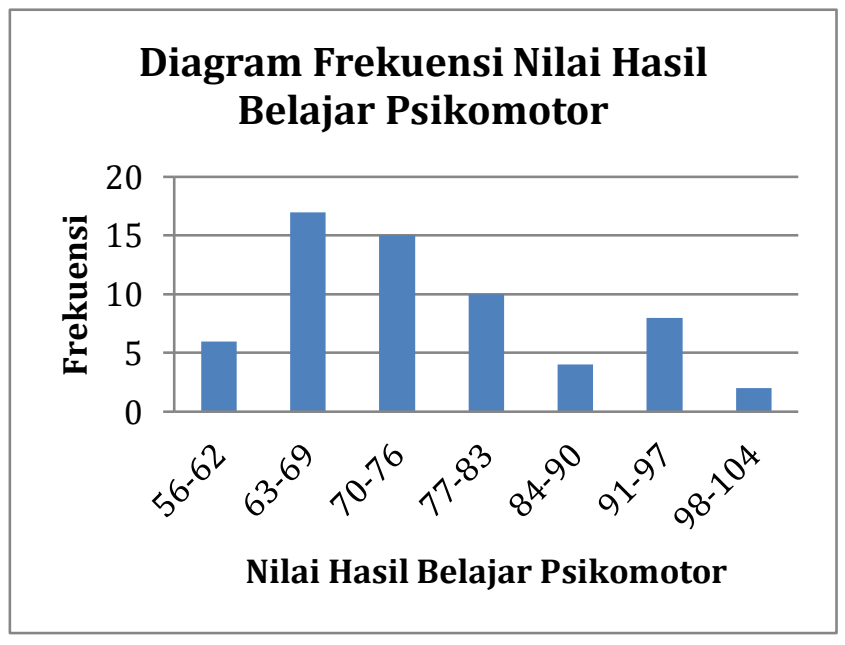

Gambar 12 Diagram frekuensi hasil belajar psikomotor

Berdasarkan Gambar 12 dapat disimpulkan bahwa nilai tertinggi berada pada interval 63-69 yang berjumlah 17 siswa dan sebaliknya nilai terendah berada pada interval 98-104 yang berjumlah 2 siswa.

Berdasarkan data hasil belajar psikomotor tersebut, dapat dilihat kriteria penilaian hasil belajar psikomotor dengan kriteria kurang, cukup, dan baik pada Tabel 25. 
Tabel 25 Kriteria penilaian hasil belajar psikomotor

\begin{tabular}{llrr}
\hline $\begin{array}{c}\text { Skala } \\
\text { (Interval) }\end{array}$ & Kriteria & Frekuensi & Persentase \\
\hline $\mathrm{X}<66$ & Kurang & 9 & $14 \%$ \\
$66 \leq \mathrm{X}<$ & Cukup & 40 & $64 \%$ \\
87 & & & \\
$\mathrm{X} \geq 87$ & Baik & 13 & $22 \%$ \\
& Jumlah & 62 & $100 \%$ \\
\hline
\end{tabular}

Berdasarkan Tabel 25 terlihat bahwa kriteria penilaian hasil belajar psikomotor siswa 9 siswa (14\%) mendapatkan kriteria kurang, 40 siswa (64\%) mendapatkan kriteria cukup, dan 13 siswa (22\%) mendapatkan kriteria baik. Maka dapat disimpulkan bahwa kecenderungan hasil kemandirian belajar siswa berada pada kriteria sangat tinggi.

\section{Pengujian Persyaratan Analisis Data}

Uji prasyarat analisis bertujuan untuk menguji apakah data yang terkumpul memenuhi persyaratan untuk dianalisis atau tidak. Adapun uji prasyarat analisis di dalam penelitian ini meliputi uji normalitas dan uji linearitas.

Uji normalitas digunakan untuk mengetahui apakah data dari variabel kemandirian beajar (X) dan hasil belajar (Y) berdistribusi normal atau tidak. Uji normalitas dilakukan menggunakan uji Kolmogrov-Sminov dengan bantuan Program SPSS 16.0 For Windows. Sebaran data dikatakan normal jika nilai signifikansi lebih besar dari 0,05 (Sig>0,05). Adapun hasil normalitas dari variabel $\mathrm{X}$ kemandirian belajar yaitu sebesar 0,626 dan hasil normalitas dari variabel $Y$ hasil belajar yaitu sebesar 0,512. Dari hasil tersebut dapat terlihat bahwa seluruh variabel memiliki hasil normalitas yang lebih besar dari 0,05 maka dapat dikatakan berdistribusi normal. Karena data dikatakan normal apabila signifikansi lebih besar dari 0,05.

Setelah di uji normalitas dari variabel $\mathrm{X}$ dan Y kemudian diuji linearitas guna untuk mengetahui ukuran derajat keeratan pengaruh dan memprediksi besarnya arah pengaruh itu. Perhitungan uji linearitas menggunakan bantuan SPSS 16.0. Jika nilai signifikansi lebih besar dari 0,05 maka pengaruh antar variabel dikatakan linear. Adapun hasil linearitas dari variabel $\mathrm{X}$ kemandirian belajar dengan variabel $Y$ hasil belajar yaitu diperoleh nilai $F_{\text {hitung }}$ sebesar 1,028 yang lebih kecil dari $F_{\text {tabel }} 4,00$ serta nilai signifikansi sebesar 0,466 yang lebih besar dari 0,05. Maka pengaruh variabel bebas dan variabel terikat pada penelitian ini dikatakan linear. Karena data dikatakan linear apabila nilai $F_{\text {hitung }}$ lebih kecil dari $F_{\text {tabel }}$ dan nilai signifikansi lebih besar dari 0,05.

\section{Pengujian Hipotesis Statistika}

Rumusan hipotesis yang akan diuji dalam penelitian ini yaitu terdapat pengaruh antara kemandirian belajar terhadap hasil belajar IPA sebagai (Ha) dan tidak terdapat pengaruh antara kemandirian belajar terhadap hasil belajar IPA sebagai (Ho). Pengujian hipotesis di dalam penelitian ini meliputi persamaan regresi, koefisien determinasi, dan uji signifikansi yang melalui uji t.

Persamaan regresi digunakan untuk meramalkan apakah variabel $\mathrm{X}$ memiliki persamaan dengan variabel $Y$ dengan rumus $\mathrm{Y}=\mathrm{a}+\mathrm{bX}$. Adapun hasil persamaan regresi dari variabel $\mathrm{X}$ kemandirian belajar dengan variabel $Y$ hasil belajar yaitu sebsesar $\mathrm{Y}=36,708+0,660 \mathrm{X}$.

Koefisien determinasi digunakan untuk mengetahui seberapa besar variabel bebas mempengaruhi variabel terikat, sedangkan sisanya dipengaruhi variabel lain. Adapun hasil persamaan regresi dari variabel $\mathrm{X}$ kemandirian belajar dengan variabel $Y$ hasil belajar yaitu sebesar 0,535 atau 53,50\% sedangkan $46,50 \%$ dipengaruhi oleh variabel lain.

Uji t digunakan untuk mengetahui ada atau tidaknya pengaruh antara kemandirian belajar terhadap hasil belajar siswa. Berdasarkan hasil uji $\mathrm{t}$ dari variabel $\mathrm{X}$ kemandirian belajar dengan variabel $Y$ hasil belajar diperoleh nilai thitung 8,306 yang lebih besar dari nilai tabel 2,000 yang dilihat dalam tabel distribusi $\mathrm{t}$ dengan $\mathrm{dk}$ 60. Serta 
diperoleh nilai signifikansi 0,000 yang lebih kecil dari 0,05. Maka Ho ditolak dan Ha diterima yang artinya kemandirian belajar memiliki pengaruh yang signifikan terhadap hasil belajar IPA siswa. Karena syarat dari uji t yaitu thitung harus lebih besar dari tabel serta nilai signifikansi yang harus lebih kecil dari 0,05 .

\section{Pembahasan}

Penelitian ini merupakan jenis penelitian korelasi fungsional yang digunakan untuk menguji pengaruh antara variabel kemandirian belajar dengan hasil belajar siswa kelas IV SDN Pajajaran Bogor, dengan populasi berjumlah 74 siswa dan sampel berjumlah 62. Pengujian hipotesis dalam penelitian ini menggunakan uji signifikansi yaitu melalui uji t. Persyaratan yang harus dipenuhi sebelum uji t yaitu distribusi data harus melalui: (1) analisis deskriptif; (2) uji prasyarat analisis yang meliputi uji normalitas dan uji linearitas; (3) analisis data meliputi persamaan regresi, koefisien determinasi. Seluruh data di analisis dengan menggunakan program SPSS 16.0 For Windows.

Berdasarkan hasil analisis deskriptif skor angket kemandirian belajar siswa, setelah ditetapkan norma kriterisasi diperoleh skor kemandirian belajar yang tertinggi sebesar 80, dan skor kemandirian belajar yang terendah sebesar 38. Serta diketahui kemandirian belajar siswa dengan tingkat kriteria sangat tinggi mempunyai frekuensi yang paling banyak yaitu 34 siswa (55\%).

Adapun hasil dari masing-masing setiap indikator dari kemandirian belajar yaitu: (1) Indikator Merencanakan Pembelajaran, setelah ditetapkan norma kriterisasi diperoleh skor yang tertinggi sebesar 24, dan skor yang terendah sebesar 10. Serta diketahui tingkat kriteria sangat tinggi yang mempunyai frekuensi paling banyak yaitu 33 siswa (53\%);

(2) Indikator Memiliki Rasa Tanggung Jawab, setelah ditetapkan norma kriterisasi diperoleh skor yang tertinggi sebesar 20, dan skor yang terendah sebesar 9. Serta diketahui tingkat kriteria sangat tinggi yang mempunyai frekuensi paling banyak yaitu 34 siswa (55\%);

(3) Indikator Mampu Mengelola Diri, setelah ditetapkan norma kriterisasi diperoleh skor yang tertinggi sebesar 20, dan skor yang terendah sebesar 8. Serta diketahui tingkat kriteria sangat tinggi yang mempunyai frekuensi paling banyak yaitu 35 siswa (56\%);

(4) Indikator Memiliki Inisiatif, setelah ditetapkan norma kriterisasi diperoleh skor yang tertinggi sebsesar 16, dan skor yang terendah sebsesar 6 . Serta diketahui tingkat kriteria sangat tinggi yang mempunyai frekuensi paling banyak yaitu 41 siswa (79\%). Berdasarkan data di atas kecenderungan hasil kemandirian belajar siswa pada setiap indikator berada pada kriteria sangat tinggi.

Berdasarkan data di atas kecenderungan hasil kemandirian belajar siswa pada setiap indikator berada pada kriteria sangat tinggi. Dan berdasarkan konfirmasi dari guru kelas IV serta beberapa orang tua murid, baik kelas IVA maupun IVB, karakteristik siswa yang memiliki kemandirian sangat tinggi ciricirinya seperti berikut: (1) Di dalam belajar tidak bergantung dengan orang lain karena mampu memecakan masalah belajarnya sendiri. (2) Mampu memilih sumber belajar yang lain, jadi siswa tidak hanya terpaku pada materi yang disampaikan oleh gurunya saja disekolah; (3) Di dalam belajar baik itu di sekolah maupun di rumah siswa yang memiliki kemandirian sangat tinggi mampu menentukan tujuan, cara, dan jadwal belajarnya sendiri; (4) Serta mampu menilai sendiri kemampuan yang dimilikinya. Hal ini sejalan dengan indikator-indikator dari kemandirian belajar yang diteliti yaitu: (1) kemampuan merencanakan yang ditandai dengan menetapkan tujuan pembelajaran dan cara belajar; (2) tanggung jawab yang ditandai dengan memiliki ketekunan dan berani memecahkan masalah; (3) mengelola diri yang ditandai dengan dapat menilai sendiri dengan apa yang dicapai dan dalam belajar tidak bergantung dengan orang lain; (4) inisiatif yang ditandai dengan memilih sumber belajar sendiri dan membuat jadwal 
belajar sendiri. Serta dapat disimpulkan bahwa skor tertinggi berada pada indikator merencanakan pembelajaran sebesar 24, sedangkan skor terendah berada pada indikator memiliki inisiatif yaitu sebesar 6 . Dan jumlah frekuensi terbanyak berada pada indikator memiliki inisiatif yaitu sebesar 41 (79\%).

Berdasarkan hasil analisis data deskriptif hasil belajar kognitif siswa kelas IV SDN Pajajaran Bogor diperoleh nilai rata-rata 73,81, simpangan baku 8,56, nilai tertinggi 89, nilai terendah 63. Sedangkan kriteria penilaian hasil belajar kognitif siswa 5 siswa (8\%) mendapatkan nilai dengan kriteria kurang, 41 siswa (66\%) mendapatkan nilai dengan kriteria cukup, dan 16 siswa (26\%) mendapatkan nilai dengan kriteria baik.

Selanjutnya, melaui lembar pengamatan pada hasil belajar afektif dan psikomotor diperoleh nilai rata-rata dari afektif yaitu 79,66, simpangan baku 10,95, nilai tertinggi 100, nilai terendah 62. Sedangkan kriteria penilaian hasil belajar afektif siswa 9 siswa (14\%) mendapatkan nilai dengan kriteria kurang, 40 siswa (64\%) mendapatkan nilai dengan kriteria cukup, dan 13 siswa (22\%) mendapatkan nilai dengan kriteria baik.

Serta diperoleh nilai rata-rata dari psikomotor yaitu 76,63, simpangan baku 10,58, nilai tertinggi 100, nilai terendah 56 . Sedangkan kriteria penilaian hasil belajar psikomotor siswa 9 siswa (14\%) mendapatkan nilai dengan kriteria kurang, 40 siswa (64\%) mendapatkan nilai dengan kriteria cukup, dan 13 siswa (22\%) mendapatkan nilai dengan kriterua baik.

Berdasarkan data seluruhnya kecenderungan hasil belajar kognitif, afektif, dan psikomotor siswa berada pada kriteria penilaian cukup. Berarti tidak hanya hasil belajar kognitif saja yang memiliki hubungan dengan hasil belajar akan tetapi juga ada hubungannya dengan hasil belajar afektif dan psikomotor. Hal tersebut didukung oleh teori yakni Sudjana, yaitu klasifikasi hasil belajar Benyamin Bloom yang secara garis besar membaginya menjadi tiga ranah, yakni ranah kognitif, ranah afektif, dan ranah psikomotoris. Dalam penelitian ini penilaian hasil belajar tidak hanya mencakup ranah kognitif saja, namun mencakup ranah afektif dan psikomotor. Dalam penelitian ini nilai kognitif dihasilkan dari penilaian tes tertulis mengenai materi sifat-sifat cahaya, sedangkan nilai afektif dan psikomotor didapatkan dari lembar pengamatan mengenai materi sifat-sifat cahaya.

Selanjutnya data di uji normalitas dan uji linearitas, guna untuk mengetahui apakah data memiliki distribusi normal atau tidak serta bersifat linear atau tidak. Hasil uji normalitas dari variabel $\mathrm{X}$ kemandirian belajar yaitu sebesar 0,626 dan hasil uji normalitas dari variabel $Y$ hasil belajar yaitu sebesar 0,512. Dari hasil tersebut dapat terlihat bahwa seluruh variabel memiliki hasil normalitas yang lebih besar dari 0,05 maka data dikatakan berdistribusi normal. Karena data dikatakan normal apabila signifikansi lebih besar dari 0,05. Sedangkan untuk uji linearitas memiliki nilai signifikansi variabel $\mathrm{X}$ kemandirian belajar dengan variabel $Y$ hasil belajar yaitu sebesar 0,466 yang dilihat pada tabel ANOVA yang bermakna bahwa data tersebut linear karena lebih besar dari 0,05. Serta nilai $F_{\text {hitung }}$ sebesar 1,028 yang lebih kecil dari $F_{\text {tabel }} 4,00$ yang berarti data memiliki keeratan hubungan linearitas atau data bersifat linear. Karena data dikatakan bersifat linear atau tidaknya dilihat dari nilai signifikansi yang harus lebih besar dari 0,05 serta dilihat dari nilai $F_{\text {hitung }}$ yang harus lebih kecil dari $F_{\text {tabel. }}$

Tahap selanjutnya yaitu analisis data dimana meliputi persamaan regresi dan koefisien determinasi. Persamaan regresi digunakan untuk meramalkan apakah variabel $X$ memiliki persamaan dengan variabel $Y$ dengan rumus $Y=a+b X$. Sedangkan koefisien determinasi digunakan untuk mengetahui seberapa besar vaiabel bebas mempengaruhi variabel terikat, sedangkan sisanya dipengaruhi variabel lain. Hasil linearitas dari variabel $\mathrm{X}$ kemandirian belajar dengan variabel Y hasil belajar yaitu diperoleh nilai $F_{\text {hitung sebesar } 1,028 \text { yang }}$ lebih kecil dari $F_{\text {tabel }} 4,00$ serta nilai signifikansi sebesar 0,466 yang lebih besar dari 0,05. Maka pengaruh variabel bebas dan 
variabel terikat pada penelitian ini dikatakan linear. Karena data dikatakan linear apabila nilai $F_{\text {hitung }}$ lebih kecil dari $F_{\text {tabel }}$ dan nilai signifikansi lebih besar dari 0,05.

Hasil persamaan regresi dari variabel $\mathrm{X}$ kemandirian belajar dengan variabel $\mathrm{Y}$ hasil belajar yaitu sebesar $Y=36,708+0,660 X$.

Hasil koefisien determinasi dari variabel $X$ kemandirian belajar dengan variabel Y hasil belajar yaitu sebsesar 0,535 atau 53,50\% sedangkan 46,50\% dipengaruhi oleh variabel lain. Pengaruh dari variabel lain tersebut bisa meliputi minat belajar, motivasi belajar, kebiasaan belajar, dan lainlain yang tidak dibahas dalam penelitian ini. Karena Slameto menyatakan bahwa faktor yang mempengaruhi hasil belajar tidak hanya kemandirian belajar saja, tetapi meliputi faktor minat belajar, motivasi belajar, kebiasaan belajar, dan faktor-faktor lain yang bersumber dari dalam diri siswa.

Selanjutnya tahap terakhir yaitu uji signifikansi yang melalui Uji $t$ untuk mengetahui ada atau tidaknya pengaruh antara kemandirian belajar terhadap hasil belajar siswa. Dari hasil penelitian ini diketahui bahwa aspek-aspek yang mencakup kemandirian belajar yang dapat mempengaruhi hasil belajar siswa yaitu aspek merencanakan pembelajaran, memiliki rasa tanggung jawab, mampu mengelola diri, dan memiliki inisiatif di dalam belajar. Kemampuan merencanakan yang ditandai dengan menetapkan tujuan pembelajaran dan cara belajar. Tanggung jawab yang ditandai dengan memiliki ketekunan dan berani memecahkan masalah. Mengelola diri yang ditandai dengan dapat menilai sendiri dengan apa yang dicapai dan dalam belajar tidak bergantung dengan orang lain. Inisiatif yang ditandai dengan memilih sumber belajar sendiri dan membuat jadwal belajar sendiri.

Hasil uji t dari variabel $\mathrm{X}$ kemandirian belajar dengan variabel $\mathrm{Y}$ hasil belajar diperoleh nilai thitung 8, 306 yang lebih besar dari nilai tabel 2,000 yang dilihat dalam tabel distribusi $\mathrm{t}$ dengan dk 60. Serta diperoleh nilai signifikansi 0,000 yang lebih keci dari 0,05. Maka Ho ditolak dan Ha diterima yang artinya kemandirian belajar memiliki penngaruh yang signifikan terhadap hasil belajar IPA siswa. Karena syarat dari uji t yaitu thitung harus lebih besar dari tabel serta nilai signifikansi yang harus lebih kecil dari 0,05 .

Hal tersebut sejalan dengan penelitian yang di lakukan oleh Reza Prayuda dengan judul "Pengaruh Kemandirian Belajar Terhadap Hasil Belajar Siswa Pada Mata Pelajaran Ekonomi di SMA". Hasil penelitian menunjukkan bahwa kemandirian belajar memiliki pengaruh terhadap hasil belajar siswa pada mata pelajaran ekonomi. Hal ini dibuktikan dengan hasil uji thitung yang lebih besar dari tabel yaitu $17.848>2.0049$ yang menyatakan bahwa Ho ditolak dan $\mathrm{Ha}$ diterima. Jadi dapat disimpulkan bahwa kemandirian belajar memiliki pengaruh terhadap hasil belajar karena dengan kemandirian belajar yang baik maka akan mendapatkan hasil belajar yang baik pula.

\section{KESIMPULAN DAN IMPLIKASI}

\section{Kesimpulan}

Kemandirian belajar yang tinggi sangat dibutuhkan di dalam proses pembelajaran. Karena dengan siswa yang memiliki tingkat kemandirian yang tinggi akan mampu mengambil keputusan yang positif untuk mengatasi masalah yang dihadapinya di dalam sekolah maupun di luar sekolah, siswa akan memiliki rasa kepercayaan diri di dalam menyelesaikan atau menjawab tugastugas IPA yang diberikan oleh guru.

Berdasarkan hasil analisis terhadap data yang telah dikumpulkan, maka dapat disimpulkan sebagai berikut:

1. Kemandirian belajar di dalam penelitian ini diketahui bahwa skor kemandirian belajar yang tertinggi sebesar 80, dan skor kemandirian belajar yang terendah sebesar 38. Serta diketahui kemandirian belajar siswa dengan tingkat kriteria tinggi mempunyai frekuensi yang paling banyak yaitu 34 siswa (55\%). 
2. Hasil belajar di dalam penelitian ini meliputi tiga aspek yaitu aspek kognitif, aspek afektif, dan aspek psikomotor.

a. Kriteria penilaian hasil belajar kognitif diketahui 5 siswa (8\%) mendapatkan nilai dengan kriteria kurang, 41 siswa (66\%) mendapatkan nilai dengan kriteria cukup, dan 16 siswa (26\%) mendapatkan nilai dengan kriteria baik.

b. Kriteria penilaian hasil belajar afektif diketahui 9 siswa (14\%) mendapatkan nilai dengan kriteria kurang, $\quad 40$ siswa (64\%) mendapatkan nilai dengan kriteria cukup, dan 13 siswa (22\%) mendapatkan nilai dengan kriteria baik.

c. Kriteria penilaian hasil belajar psikomotor diketahui 9 siswa (14\%) mendapatkan nilai dengan kriteria kurang, $\quad 39$ siswa (63\%) mendapatkan nilai dengan kriteria cukup, dan 14 siswa (23\%) mendapatkan nilai dengan kriteria baik.

3. Terdapat pengaruh yang signifikan antara kemandirian belajar terhadap hasil belajar siswa kelas IVA dan IVB SDN Pajajaran Bogor. Hal ini sesuai kriteria pengujian tolak $\mathrm{H}_{\mathrm{o}}$ berarti terdapat korelasi positif yang terlihat dari hasil pengujian hipotesis statistika pada hasil uji t yaitu diperoleh nilai thitung sebesar 8,306 yang lebih besar dari tabel 2,000 serta nilai signifikansi 0,000 yang lebih kecil dari 0,05 maka Ho ditolak dan Ha diterima.

\section{Implikasi}

Hal ini memberikan beberapa implikasi antara lain seperti pentingnya siswa memiliki aspek merencanakan pembelajaran, memiliki rasa tanggung jawab, mampu mengelola diri, dan memiliki inisiatif di dalam belajar agar tercapainya tujuan belajar siswa dengan baik. karena dengan kemandirian belajar yang baik maka akan mendapatkan hasil belajar yang baik pula.

Serta dengan mendorong siswa untuk berpartisipasi aktif di dalam pembelajaran; memberi kebebasan kepada siswa untuk mengembangkan lingkungan, mendorong rasa ingin tahu mereka; serta memberikan motivasi kepada siswa untuk mengembangkan kemandirian belajarnya maka kemandirian belajar dan hasil belajar IPA akan meningkat.

\section{DAFTAR PUSTAKA}

Arifin Z. 2012. Penelitian pendidikan. Remaja Rosdakarya, Bandung.

Azwar S. 2016. Teori dan pengukurannya. Pustaka Pelajar, Yogyakarta.

Muhidin AS dan M Abdurahman. 2009. Analisis korelasi, regresi, dan jalur dalam penelitian. Pustaka Setia, Bandung.

Sudijono A. 2014. Pengantar statistik pendidikan. Raja Grafindo Persada, Jakarta.

Sugiyono. 2012. Metode penelitian pendidikan. Alfabeta, Bandung.

Sugiyono. 2015. Metode penelitian kuantitatif, kualitatif, dan R\&D. Alfabeta, Bandung. 